\title{
Bridal Make Up Jembrana Regency, Bali Province
}

\author{
Ni Ketut Widiartini ${ }^{1 *}$, Kadek Hermayani ${ }^{2}$ \\ ${ }^{1,2}$ Family Welfare Education Study Program, Faculty of Engineering and Vocational, Ganesha University of Education \\ Singaraja, Indonesia \\ *Corresponding author,e-mail: ketut.widiartini@undiksha.ac.id
}

\begin{abstract}
This study aimed at describing the bridal makeup of Agung Jembrana, the meaning and of the bridal makeup of Agung Jembrana. This study employed descriptive qualitative research. The research location of this study was at LKP W \& W Asri. This study used observation and interview method for collecting the data. The research instruments were observation sheet and interview guidelines. The results indicated that, the bridal makeup of Agung Jembrana consisted of (a) makeup, included: serinata, eyebrows. (b) the bride's hairdo, included: white menori flower, bud-white menori flower, and sanggul gelung tanduk. Meanwhile, the groom, included: udeng. (c) bridal gowns, included: tapih wali, kamen songket, scarves embroidered by gold thread, cerari scraves, black velvet shirt. The groom, included: full of kamen mastuli, saput songket, umpal cerari, and black velvet shirt. (d) bridal accessories, included: subeng, pending belt, naga satru bracelets, and binar necklace. The groom, included: rumbing, naga satru bracelets and anklets, keris, and the flower put on the udeng.

Keywords: mean, great bridal makeup Agung, regency, Jembrana
\end{abstract}

\section{INTRODUCTION}

Pakem is a characteristic, a characteristic in a large Indonesian dictionary means that it is special or special in every region and not owned by other regions (http://kbbi.web.id/khas). Accessed August 5, 2019.

Balinese bridal make up is a make up that includes makeup, hair styling, clothing and accessories in the form of metal accessories and fresh flowers. Balinese bridal makeup can not be separated with the characteristics (grip) in each area in accordance with the legacy of previous ancestors. The Province of Bali is a region that is still thick with art and culture inherited from previous ancestors as well, with its make-up where each regency in Bali has its own characteristics, it can be seen in the makeup, fashion, hairstyle and accessories used where each - each part has its own meaning according to its shape.

According to Lina Wiartini (2016) Karangasem Bridal Makeup in Bali Province said that Agung bridal make-up that looks very unique with its own characteristics. Agung Karangasem's bridal makeup uses a bastard's scarf made by weaving, using padded as her hairdo. In cosmetology this is identical to using clothing that is woven and using songket.

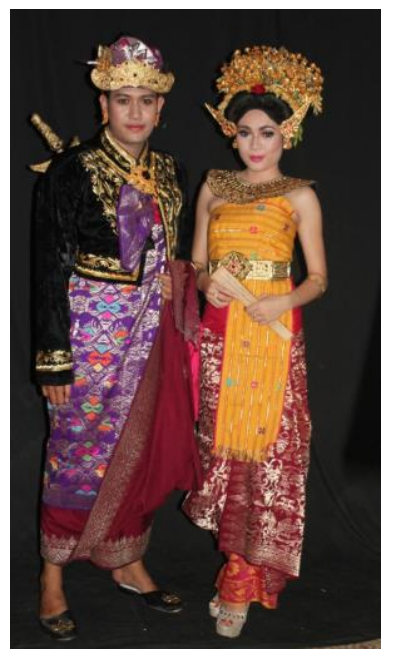

Picture1. Bridal Make-Up Karangsem

Source: Lina Wiartini (2016) 
Furthermore according to Rizki Ari Safitri (2017) said that the bridal makeup of the Buleleng Style also has its own characteristics on the bridal make-up that can be seen from the clothing using a thin red curly chisel that is used on the shoulders of the bride in a triangle shape.

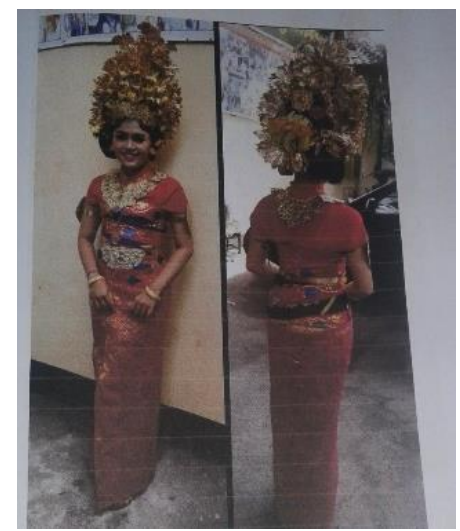

Picture 2 Bridal Make-up Klungkung

Source: Putri Astuti (2017)

According to Putri Astuti (2017) said that the great bridal makeup of Klungkung has a distinctive feature by using prada and songket that can beautify the bride and in the hairdo using semi-wrap and gonta sari are typical Klungkung Regency.

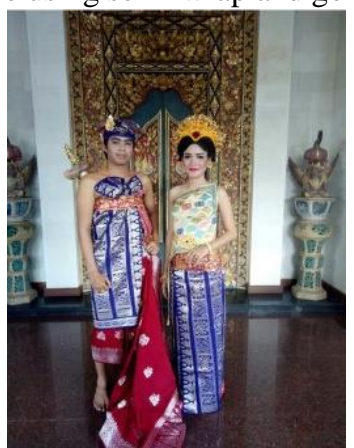

Picture 3. Bridal Make-Up Klungkung

Source: Putri Astuti (2017)

According to Dwi Pujiastuti (2016) The Study of Badung Style Bridal Make-Up and Clothing which explains that the Balinese-style makeup and attire of Badung style is a make-up that is thick with its grips since long ago. This make up is used in ceremonies performed in the Badung area. Badung style bridal make up has a characteristic on her head decoration such as petitis, design, puspa lembo, golden cempaka flower, stamp flower, Kompyong.

Bridal make up is a procedure used for brides. Bridal make up must have the power to change the face to be more radiant and look special while maintaining a natural beauty that is personal with the aim of beautifying the face, making the face look more cheerful and awake and compensating for the state of a wedding. (riaspengantinke5.blogspot.com) visited on 27 January 2019. Where the makeup on Balinese brides is identical to using forehead decoration or what is called serinata. With this serinata makes Balinese brides will look more beautiful and elegant.

In the same area of Java, using forehead decoration, it's just a different name and shape, where in Yogya the forehead decoration is called paes. Furthermore according to (Khofifal, 2013) the solo bridal make-up also uses forehead decoration consisting of elephants, clasps, dropper and goddess. Then in the study (Clarina Novi Olgaria, 2017) the traditional Javanese bridal funeral of Jember Sari Timut said that the forehead decoration uses paes consisting of ovate, ronsoto and godek.

Based on the explanation above, it states that in each district has characteristics, both in terms of motifs, colors and places of placement that can be realized in facial makeup, hairdo, clothing and accessories. Each regency in Bali has unique characteristics or traditions, one of which can be seen in the bridal make-up that has its own characteristics as well as in Jembrana Regency, which has its own characteristics in fashion, hairdo and accessories where the fashion used using a typical Jembrana weave that has a full and identical mastuli motif by using a black velvet dress that is used on brides and grooms. So with this problem the author will describe "The Great Bridal Makeup of Jembrana". 


\section{RESEARCH METHODS}

According to Hidayat Syah (2010) defines that the descriptive research method is a research method used to find the broadest possible knowledge of the object of research at a particular time.

The object used in this study is the grand bridal makeup Jembrana. The research was conducted at LKP W \& W Asri and LKP Sekar Taji. Data collection techniques using observation and interview techniques.

\section{RESEARCH RESULTS AND DISCUSSION \\ Research results}

Based on the results of interviews with a number of informants stated that the makeup of the great bride of Jembrana has a characteristic on the hairdo using white menori flowers and the clothing used is typical Jembrana district.

The grand bridal make up of Jembrana uses standard or standard make-up on the forehead decoration called serinata. The shape of the forehead decoration used is curved beautifully as if adding to the beauty of the bride. The shape of the eyebrows is curved beautifully with a blackish brown color and at the middle of the eyebrows is given a red dot or called a gecek.

Based on the results of interviews with a number of informants stated that the steps in putting on the bride's makeup as follows:
1. Clean the bride's face

2. Using a moisturizer that is kept until the neck

3. Next shading, powder and solid powder.

4. Next to form eyebrows. The eyebrows are made with beautiful curves with black-brown eyebrows, with the beginning of making brown eyebrow lines then colored with black.

5. Then apply eye decoration (eyeshadow) that is on the eyelids using a yellow color, on the chrouge using black and at the top using cream colored hightlight.

6. Next apply the blush on the cheekbones.

7. Then make serinata in the following way: first make a point in the middle of the forehead hair growth line, parallel to the gecek or trumpet, from this point measure left and 2 finger widths. From the right point to the left point whose lines are curved and rounded inwards, from the point of the eyebrows, measure upwards as wide as the thumb is slightly pressed, then connect the point made above. by painting a slightly outward curved line, after the serinata is formed, then check again properly, symmetrical left and right seen, so that the shape is balanced.

8. Finally apply lipstick on the lips with a pink or red color.

Picture 4. Serinata (Source: Mertami, 1993:28)

The groom's makeup is only natural using powder, eyebrows, eyeliner, lip blush and blush.

Hairdo is the final stage of the hair styling process. Hair styling can characterize a person. Likewise the bridal hair styling in Bali between one and another is very different and has its own characteristics. According to (Mertami, 1993: 25) hair styling in Balinese bridal makeup is called "semi". Semi is the shape of the front which characterizes that of Balinese bridal makeup.
The hairstyle in the bridal makeup of the great Jembrana uses a bun, bun, horn which is placed on the back and semi using a semi-clawed shrimp. In the hairdo is divided into two parts, namely the front is made in the spring on the right and left, then at the back tied 7 fingers high from the line of the back of the head. Here are the steps to do the hairdo on the bridal makeup big Agung Jembrana: 
Table 1. The Steps To Do The Hairdo the steps to do the hairdo on the bridal makeup Picture (Source: personal

1. First divide hair into two parts.

2. The front is semi-shaped and the back is tied. Then attach the pine hair and then the shape of the pine hair with a cone shape, trim it.

documentation)

3. Next, attach the flower menori flower on the front, then attach the design above the white menori flower, attach the red rose, then take the golden flower and then form the golden flower, amounting to 21 to 25 stems with a tapered triangle starting from the installation of the menori flower white

4. Next attach the design above the white menori flower.

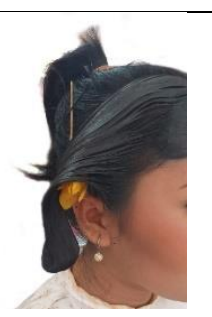

4. Next attach the design above the white menori flower.
5. Pair red roses

6. Then take a golden flower and then form a golden flower, amounting to 21 to 25 stems with a triangular shape tapered pairs of gold flowers that are 9, 7, 5, 2, 1,1.

7. Then attach the puspa lembo to the bun and the bun is placed right and left.

8. Pair white cempaka flowers, yellow and sandat beside the bun bun horn. Finally, the garuda is lying in the middle behind the hood. 
The Meaning of Great Jembrana Bridal Makeup:

1. Facial make up:

a. Serinata has the meaning contained in it is signifying that an adult where someone who is married must have an adult mind in living the household ark.

b. Eyebrows have the meaning of a universal and abstract idea about beauty.

2. Hairdo:

c. Eyeshadow symbolizes glory and prosperity.

a. Shrimp semi claw meaning as a symbol of balance where when someone is married must have a balanced attitude between mind, body and soul.

b. White menori flower has a meaning as a symbol of purity, so a person must still have a caring heart and remain humble.

c. The meaning of red roses is that it symbolizes the strength of a woman's heart, as well as a bride when it is already marriage must still have the strength of the heart in facing a new life.

d. White and yellow cempaka flowers symbolize samara and ratih. Cempaka flowers white, yellow, and sandat have meaning that symbolizes Brahma, Vishnu and Iswara.

e. Bun bun horn is a symbol of courage, where the symbol of courage indicates that the bride must be strong in facing her new life.

f. Garuda might mean that makeup signifies great or ultimate.

3. Clothing consists of:

a. Tapih wali has a meaning as having a meaning as a symbol of the youth of a bride and

b. Kamen songket has a meaning as the beauty and luxury of the bride and groom where the bride will look more luxurious.

c. A gold thread embroidered shawl is a shawl that is used on the chest that functions as a breastplate. Therefore, this scarf is used to symbolize the area has its own characteristics of the beauty of the weaving.

d. In the groom, Kamen mastuli has full meaning as the majesty and authority of a king as well, a man will look more authoritative.

e. Kamen songket or saput is kamen used after kamen mastulih full.

f. Cerari patterned scarves (umpal) are used as umpal. Umpal has the meaning of the symbol of Lord Shiva in its manifestation as returning its origin.

4. Accessories:

a. Subeng signifies harmony of knowledge and attitude, so as to prevent selfishness as well as a bride can maintain the attitude and selfishness so that households remain happy and harmonious.

b. Twinkle necklace is a jewelry that is used on the neck which amounted to 9 liotin which symbolizes the increasing number of liotin as a high level of one's social status.

c. The meaning contained in the pending belt is to symbolize being able to bind or limit yourself as a wife.

d. Nagasatru bracelet meaning symbolizes so that the bride can curb herself. The groom consists of: rumbing, keris, nagasatru bracelets and anklets.

e. Rumbing is the ear ornament used on the groom, with the meaning contained in rumbing is the harmony of knowledge and attitude, to prevent selfishness as well as a bride can maintain her attitude and selfishness so that the household remains happy and harmonious.

f. Keris is used by the groom to add courage, agility and authority to the wearer. The meaning of the kris symbol for a marriage is the symbol of purusa and pradana (male and female). Bracelet is one of the body accessories used to decorate hands.

g. The bracelet symbolizes so that the bride can curb herself

\section{DISCUSSION}

According to literature studies and research results the meaning contained is almost the same, but if examined deeper there are differences in makeup, hairdo, clothing and accessories.

a. The results showed that face makeup uses forehead decorations that adjust the shape of the face, eyeshows using cream colored highlights. While the Balinese bridal bridal makeup highlights use a golden yellow color.

b. The results showed that the hairstyle of the great bride of Jembrana used semi-clawed shrimp, bun of shrimp claw, white menori flowers, bouquets, red roses, golden flowers, garuda mungkur, puspa lembo flowers, garuda mungkur, white cempaka flowers, yellow and sandat. Meanwhile, according to the opinion (Putri Astuti, 2017) hairdressing, namely semi-convolution, Konta saris, roses, white cempaka, yellow, sandat, golden reong flowers, Kompyong flowers, golden tips, mandel kletek bun.

c. The results showed that the grand wedding dress of Jembrana using the bride consisted of: tapih wali, kamen songket, gold thread embroidered shawl, cerari shawl and black velvet shirt. While men's clothing consists of: tapih full mastuli, kamen songket, umpal cerari and black velvet shirt. Meanwhile, according to the opinion (Lina Wiartini, 2016) the bride's fashion includes: the use of tapih, kamen songket, stagen, slendang blebet china silk and finally the scarf bangs. The groom uses: songker handkerchief, belt / stagen, full seam / handkerchief, umpal, embroidered velvet shirt, and destar.

d. The results showed that the accessories of the Jembrana grand bride consisted of Agung 
Jembrana bridal makeup accessories consisting of: pending belts, dawn, bracelets and twinkle necklaces. While Groom's accessories include: kris, nagasatru and foot bracelets, golden buds and rumbing. Meanwhile, according to the opinion (Rizki Ari Safitri, 2017) Agung bridal make-up accessories, Agung Khasung Buleleng, consist of (women): sunny, badong, dollar pendants, kana bracelets, paris bracelets, eyed rings, middle-aged gold belts. Whereas (men): togogs, dollar necklaces, eyed rings and paris bracelets.

e. The results showed that the garuda mungkur has the meaning that the level of makeup is the most regal or primary. While in the opinion (Delia Wulansari, 2015) the form, function and meaning of cosmetology and the procession of the grand Balinese wedding ceremony in Bali garuda mungkur has the meaning of fertility, fertility and authority.

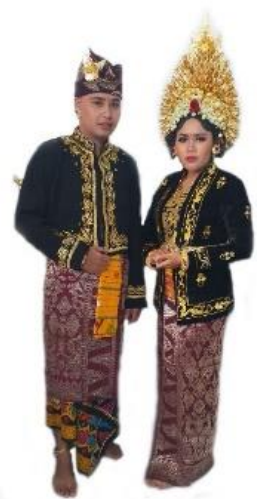

\section{CONCLUSIONS}

Based on the results of research conducted it can be concluded as follows: The parts of Agung Jembrana bridal make up which consist of face makeup, hairdo, clothing and accessories where the make up in each district has its own characteristics in accordance with the relics of their forefathers and in accordance with the customs of their respective regions. Similarly, the bridal make-up Agung Jembrana has its own characteristics and is very different from bridal make-up in other districts which can be seen in terms of facial makeup, hairdo, clothing and accessories used where this cosmetology dress is indeed the characteristic fabric of the Regency Jembrana is a typical Jembrana weave. In the hairdo is also typical to use white menori flowers. Here are the parts: Agung Jembrana bridal makeup consists of: face makeup used on the bride consisting of: serinata, eyebrows, eye decoration (eyeshadow), blush (blush on), lipstick (lipstick) and face shading. Whereas the groom does not use too much makeup, only uses makeup naturally. Hairdo consists of: semi-claw shrimp, bun horn, white menori flowers, white cempaka flowers, yellow, sandat, roses, white flowers menori buds, designs, golden flowers, hoods, garuda mungkur and puspa lembo. The groom consists of udeng. Clothing used on brides consists of: tapih guardians, kamen songket, cerari scarves, gold embroidered scarves and black velvet shirts. Whereas the groom consists of: kamen mastuli full, saput or kamen songket, umpal cerari and black velvet shirt. Accessories used on the bride consist of: dawn, twinkle necklaces, pending belts and nagasatru bracelets. While the groom consists of: a dagger, rumbing, udeng flowers, nagasatru bracelets and anklets.
Parts of the bridal make-up Agung Jembrana have their own functions and meanings.

\section{SUGGESTION}

Based on the discussion of research results and conclusions, suggestions can be made as follows: 1. For the community: so that the community continues to maintain the bridal make up of Agung Jembrana without leaving the standard of this makeup. 2. Makeup artists in Jembrana Regency must participate in maintaining the makeup of Agung Jembrana bride by means of socializing, introducing the Jembrana community and the general public in the Province of Bali.

\section{REFERENCES}

[1] Astuti, Putri“Tata Rias Pengantin Kabupaten Klungkung. e-journal Bosaparis Vol 8, Universitas Pendidikan Ganesha, No 2. 2017

[2] Ari Safitri, Rizki. "Tata Rias Pengantin Agung Gaya Buleleng". e-journal Bosaparis Universitas Pendidikan Ganesha, Vol 8, No 2. 2017

[3] Delia, Wulansari. 2015. "Bentuk, Fungsi dan Mkana Tata Rias dan Prosesi Upacara Perkawinan Bali Agung di Bali. e-Journal. Volume 04. Nomor 02 Tahun 2015. Universitas Negeri Surabaya.

[4] Khofifal, "Karakteristik Tata Rias Pengantin Solo", e-journal Universitas Negeri Surabaya, Vol 02, Nomor 02, Tahun 2013.

[5] Lina Wiartini, Ni Kadek“ Study tentang Tata Rias Pengantin Agung Kabupaten Karangasem 
Provinsi Bali”. e-Journal Bosaparis Universitas Pendidikan Ganesha, Vol 4, No 1. 2016.

[6] Mertami, Nyonya . 1993. Tata Rias Pengantin Bali: PT. UPADA SASTRA.

[7] Pujiastuti, Dwi. 2016. "Tata Rias dan Busana Pengantin Bali Gaya Badung”. e-journal
Bosaparis Universitas Pendidikan Ganesha 2016.

[8] Novi, Clarina. 2015. "Kajian Tata Rias Pengantin Tadisional Jember Sari Jawa Timur". e-Journal Universitas Negeri Surabaya. 